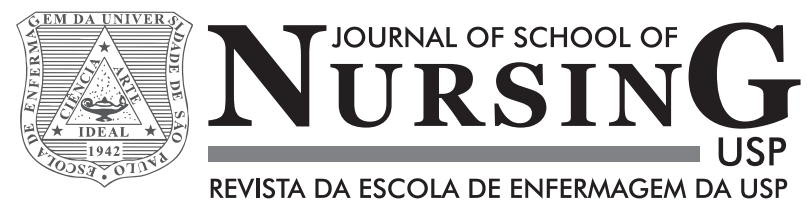

\title{
Perioperative thirst: an analysis from the perspective of the Symptom Management Theory*
}

\author{
Sede perioperatória: uma análise sob a perspectiva da Teoria de Manejo de Sintomas \\ Sed perioperatoria: un análisis bajo la perspectiva de la Teoría del Manejo de Síntomas
}

Marilia Ferrari Conchon', Leonel Alves do Nascimento², Lígia Fahl Fonseca ${ }^{3}$, Patrícia Aroni ${ }^{4}$

\footnotetext{
* Article extracted from the master's thesis entitled "Eficácia do picolé de gelo para manejo da sede no pós-operatório imediato: ensaio clínico randomizado", Master's program in Nursing, State University of Londrina in 2014.

${ }^{1}$ Master's Student, Master's Program in Nursing, State University of Londrina, Londrina, PR, Brazil.

${ }^{2}$ Master's in Nursing from the State University of Londrina, Londrina, PR, Brazil.

${ }^{3}$ Adjunct Professor, Department of Nursing, State University of Londrina, Londrina, PR, Brazil.

${ }^{4}$ Assistant Professor, Department of Nursing, State University of Londrina, Londrina, PR, Brazil.
}

\section{ABSTRACT}

A theoretical study aimed to analyze the existing knowledge in the literature on the perioperative thirst symptom from the perspective of Symptom Management Theory, and supplemented with the experience of the study group and thirst research. Thirst is described as a very intense symptom occurring in the perioperative period, and for this reason it cannot be ignored. The Symptom Management Theory is adequate for understanding the thirst symptom and is a deductive theory, focused on the domains of the Person, Environment and Health / Illness Status, as well as on the dimensions of Experience, Management Strategies and Symptom Outcomes. Using the theory leads us to consider perioperative thirst in its multifactorial aspects, analyzing the interrelation of its domains and dimensions in order to draw attention to this symptom that has been insufficiently valued, recorded and treated in clinical practice.

\section{DESCRIPTORS}

Thirst; Signs and Symptoms; Perioperative Nursing; Nursing Theory. 


\section{INTRODUCTION}

Thirst is a powerful symptom that surpasses all other sensations. In the presence of thirst, the longing for water is so imperative that it cannot be ignored. Described by patients as an intense discomfort, it has a negative impact on surgical experience and has high incidence in the immediate postoperative period, reaching $75 \%{ }^{(1)}$. Even so, the assessment, measurement and adoption of thirst-relief strategies for the perioperative period - when they are implemented - occur discontinuously, are non-standardized and not based on scientific evidence ${ }^{(1)}$.

There is a scarcity of studies evaluating this discomfort and proposed methods for their control. National and international anaesthesiologist and perioperative nursing associations still disregard this construct in their manuals of best practices - they are not even listed in the classifications of nursing diagnoses.

To meet this challenge of a lack of knowledge about this discomfort in surgical patients, a study and Research Group in Perioperative Thirst (GPS) was formed at the State University of Londrina in order to assist in the construction and systematization of knowledge concerning thirst, as well as strategy development for its management.

Because it is a complex and multifactorial symptom, it cannot be considered in an independent or isolated manner. So this theoretical reflection aims to analyze the existing literature about perioperative thirst symptom, from the perspective of Symptoms Management Theory, supplemented by the GPS experience.

\section{Theory of Symptoms Management}

The Symptoms Management Theory constitutes the theoretical framework of this study because it approaches specific symptoms as a multidimensional process. It was initially developed by the effort of many researchers, members of the University of California at San Francisco School of Nursing - Symptom Management Faculty Group in 1994(2). Based on experience with several health problems, they devised a deductive symptoms management model focused on three interactive dimensions of symptom management: experience of the symptom, management strategies of the symptoms and symptom outcome, with the premise that effective management of a symptom should include these three dimensions ${ }^{(3)}$.

The model was revised in 2001 (Figure 1), and the following contexts were added to the domains of nursing: person, environment and health / illness status ${ }^{(3)}$ :

In 2008, the model underwent further review and was consolidated as the Symptom Management Theory ${ }^{(2)}$. The choice of this theory for the analysis of thirst in the perioperative period is justified by its basic assumptions, which can be applied to the study and understanding of the construct of thirst: (a) it is based on the perception of the individual experiencing the symptom and self-reporting it: perioperative thirst detection is primarily based on the verbal report of the patient; (b) it is not necessary that subjects present the symptom for the application of this theory, just be at risk of developing it: knowing that the surgical patient has a high risk for developing thirst symptom can lead to planning and

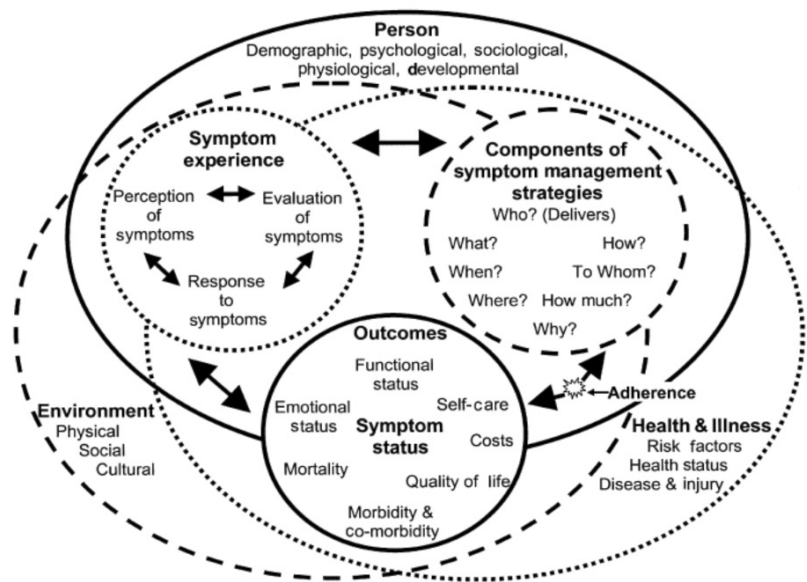

Figure 1 - Revised Model of the UCFS Symptom Management Model*

Source: Dodd M, et al.(3)

implementing prevention, assessment and management in advance; (c) when the patient has some difficulty in communicating, a report from the parent or guardian can be considered as a reliable source of information for evaluation and intervention in regards to the symptom: in relation to thirst, this assumption may apply to pediatric patients with special needs and the elderly, and in this case, caregivers may perceive and recognize behaviours of discomfort more easily; (d) all symptoms of discomfort must be addressed; signs and symptoms indicative of thirst and dry / chapped lips, dry mouth / throat need to be evaluated and addressed in an integrated and comprehensive manner; (e) the strategy can be directed to an individual, group, family or work environment: to avoid the discomfort of thirst since surgical patients are a group at risk for this symptom, actions rising from evaluation protocols and symptoms management should be implemented; (f) it is a dynamic process in which the impact of symptoms are individual on the one hand, and on the other, they depend on the Nursing domain influences of the person, environment and health / illness: perception, verbalization and responsiveness of thirst management strategies are individual, in accordance with the bio-psychosocial characteristics which are influenced by the three domains ${ }^{(3)}$.

According to this theory, a symptom is "a subjective experience that reflects changes in the biophysical functioning, in feelings or cognition of an individual"(3).

The theory is recognized as a multidimensional process, and requires consideration of all the elements to be effective ${ }^{(3)}$. Perioperative thirst is, hereafter, analyzed from the perspective of the Domains (Person and thirst; Environment and thirst and State of health/illness and thirst) and Dimensions (Experience, Management Strategies and Symptom Outcomes) of the Symptom Management Theory.

\section{Domains of Nursing Science}

\section{THE DOMAIN OF PERSON AND THIRST}

The analysis of thirst within the person domain elucidates some of the many individual factors that affect the 
emergence and perception of this symptom. Personal variables such as demographic, psychological, sociological and physiological factors are intrinsic to the way the individual views the experience of a symptom and responds to it (Figure 1$)^{(3)}$. In this perspective, voluntary fluid intake is a behavior affected by social and psychological factors ${ }^{(4)}$, and the perception of thirst varies according to age groups.

In older adults, physiological control mechanisms associated with thirst are altered by the reduced sensitivity of the body's volume receptors, plus there is possible cortical brain dysfunction and alterations in the release of antidiuretic hormone $(\mathrm{ADH})$. When exposed to hyperosmotic and / or hypovolemic stimuli, older adults have large increases in plasma osmolality, sodium concentration and $\mathrm{ADH}$ levels ${ }^{(5)}$. In contrast, urinary osmolality is decreased, they report less thirst sensation and even when they have free access to water, they drink smaller volumes which can occur for fear of incontinence, inaccessibility to toilets and immobility ${ }^{(6)}$.

The control of thirst mechanisms also shows different behavior in children, who often present dehydration after minor physical efforts; their rehydration is usually inadequate and the absence of thirst can occur for extended periods ${ }^{(5)}$. There is lack of scientific evidence that addresses the correlation between thirst and children, considering physiological and osmoregulatory aspects and its proper management.

As to gender, emerging evidence shows that girls have a more favorable attitude to hydrate themselves than boys, and women show a decrease in verbal reaction time compared to men exposed to the same conditions of dehydration of not receiving fluid during a 24 -hour period ${ }^{(7)}$. There are not yet studies that evaluate the influence of gender in triggering thirst.

When it comes to psychological factors, some of the feelings repeatedly linked to the perioperative period are fear, insecurity, stress and anxiety ${ }^{(8)}$. Surgical stress, nausea and hypoglycaemia stimulate the secretion of $\mathrm{ADH}$ and therefore also trigger the sensation of thirst.

With regards to the physiological aspects of thirst in humans, it is determined by osmotic and blood volume changes that almost always occur after the loss of solute and water, denominated respectively as osmotic thirst and hypovolemic thirst ${ }^{(9)}$.

Osmotic thirst, or intracellular dehydration, results in response to an imbalance between increased cell tone and failure of compensatory mechanisms to conserve body fluids ${ }^{(9)}$ . These changes in osmolarity are easily detected by osmoreceptors in the brain's circumventricular organs ${ }^{(10)}$ and cells from the same brain region, which synthesize two important neuro-pituitary peptides in the thirst adjustment mechanism: $\mathrm{ADH}$ and natriuretic hormone ${ }^{(11)}$. There are also peripheral and visceral osmoreceptors active in the regulation of fluid that can be detected in the regions of the gastrointestinal tract, the oropharyngeal region, the splanchnic mesentery, hepatic portal vein, and also in the liver ${ }^{(10-11)}$.

Normal plasma osmolarity is maintained within a narrow range, and a range of $1 \%$ to $2 \%$ more than normal is responsible for $70 \%$ of the stimuli to elicit thirst, releasing $\mathrm{ADH}$ in minutes ${ }^{(10-11)}$. Moreover, a proportional decrease in osmolarity leads to osmotic dilution, triggering the appetite for salt from the sodium deficiency due to loss of extracellular fluid. This is sometimes perceived as thirst, only there is no relief from simple water intake: it also requires the replacement of solute ${ }^{(10-11)}$.

In hypovolemic thirst, fluctuations in the volume and intravascular pressure are less sensitive than the osmotic changes, requiring a decrease of approximately $10 \%$ of the plasma volume to trigger it ${ }^{(11)}$. This fact is relevant when one considers that the surgical patient is exposed to considerable blood volume changes - blood loss that may result from the surgery - and the changes in intravascular pressure as a result of hypovolemia or from the effect of using vasoactive drugs during anaesthesia.

The massive blood changes activate a neuro-hormone complex that release $\mathrm{ADH}$, corticotropin and glucocorticoids, activating the renin-angiotensin-aldosterone system and adrenergic agonists epinephrine and norepinephrine, in order to restore blood volume ${ }^{(9)}$.

In turn, the baroreceptors located in the walls of the great/large vessels activate the release of atrial natriuretic peptide, inhibiting secretion of renin, ADH and aldosterone, reducing the demand for water ${ }^{(11)}$.

The possible correlation of socio-cultural aspects involved in perioperative thirst with mobilizing mechanisms of thirst is still not yet clarified. GPS has been conducting studies of a qualitative approach in order to clarify and deepen understanding of these influences.

\section{THE DOMAIN OF ENVIRONMENT AND THIRST}

The environment concerns the association of conditions or the context in which each symptom occurs, including physical, social and cultural variables ${ }^{(3)}$. The surgical environment imposes specific stressors onto the patients, contributing to worsening their thirst. The impossibility of receiving water, remaining in air-conditioned operating rooms, conducting open surgical procedures - which induces tissue dehydration - administration of oxygen for prolonged periods in the intra and postoperative periods, and the inevitable permanence of the opening of the oral cavity by intubation are factors that greatly intensify patient's thirst.

When it comes to cultural aspects, it is argued that the patient needs to have the courage to express their discomfort due to thirst and trust that their symptoms will be evaluated as important. One reason that may cause the patient to not spontaneously verbalize their thirst is the constant affirmation by staff about the need for preoperative fasting.

However, the cultural dimension of interference in the perception that the patient has perioperative thirst and in their willingness to communicate it to the team is still unknown.

\section{THE DOMAIN OF HEALTH / ILLNESS STATE AND THIRST}

This area comprises variables specific to the state of health or illness of an individual, including procedures performed for the restoration of their clinical condition ${ }^{(3)}$.

Thirst is of key importance for fluid maintenance and electrolyte balance in the body, and acts as a regulatory incentive for water intake. The surgical patient is exposed to 
a confluence of factors which cause them to feel thirsty, such as the need for preoperative fasting maintenance, intraoperative bleeding and heat loss from breathing and sweating $^{(1,9,11-12)}$.

Non-regulatory factors are also related to thirst in surgical patients. Besides fear, anxiety and tracheal intubation, use of drugs that reduce the production and secretion of saliva decreasing the moistness of the oral cavity, resulting in stimulating thirst ${ }^{(9)}$.

Preoperative fasting aims to prevent the occurrence of aspiration pneumonia ${ }^{(12-13)}$. Anaesthesiologist Societies indicate two hours of fasting for clear liquids and six hours for solid foods. However, contrary to such recommendations, overly prolonged fasting periods ranging from 8 to 37 hours ${ }^{(1,12-13)}$ have been encountered in practice. The period of fasting continues onto the immediate postoperative period, thereby increasing thirst ${ }^{(12)}$.

The components of the Symptom Management Theory contemplate and address the following dimensions: Symptom Experience, Management Strategies and Outcomes.

\section{Symptom Management Theory dimensions}

\section{SYMPTOM EXPERIENCE}

\section{Perception of Symptom}

The symptom experience includes individual experience, assessment of the significance and response to the symptom (Figure 1$)^{(3)}$. The perception of a symptom depends on internal neurophysiological functions and it is questioned to what extent they can be changed or influenced by the person's condition and the treatment of their symptoms ${ }^{(3)}$.

The surgical patient begins to have the perception of thirst symptom as they recover proprioception and the ability to identify environmental stimuli during recovery from anaesthesia. Patients' attitudes facing the thirst stressor, vary according to their culture, knowledge, and pre-operative instructions, among others. Their reaction and expression may be anchored on past experiences - for example, a case in which a thirsty polytraumatized patient was told that he could not drink water as he was to be observed for bleeding and possible surgery. In a later situation, he associated thirst to clinical worsening, which interfered with his decision to verbalize it.

In clinical practice, GPS members observed that only $13 \%$ to $18 \%$ of patients who feel thirsty verbalize it spontaneously. The two main reasons causing the patient to be silent are concern about the surgery being cancelled for breaching preoperative fasting and possible occurrence of vomiting - this is strongly reinforced by the team, justifying the need to fast. This becomes the most important factor for the patient to be silent, even after surgery.

Studies that GPS has conducted, demonstrate that the discomfort caused by thirst in the perioperative period is very strong or greater than pain, capable of generating distress and temporary incapacity. In comparing it with hunger, patients emphatically report that thirst is much more urgent and surpasses all other sensations.
Not knowing strategies that alleviate thirst without putting the patient at risk contribute to patients not verbalizing their thirst and accepting it as an inevitable discomfort.

\section{Evaluation OF Symptom}

Comprises a complex set of factors that characterize it: intensity, location, temporal nature, frequency and impact (Figure 1$)^{(3)}$. It also includes evaluating the threat and danger imposed by the symptom ${ }^{(3)}$.

To evaluate thirst symptoms, methods should be chosen according to what is wanted to be investigated, but the literature does not reveal any solidly reliable measure for the sensation of thirst ${ }^{(11)}$.

There is research being conducted for the identification, perception and measurement of thirst in order to develop methods to evaluate it. A visual analog scale has been used due to its ability to measure subjective and self-reported symptoms $^{(1,4,14)}$. An assessment scale for dialysis patients has also been validated. This scale covers three domains: duration, frequency and discomfort ${ }^{(15)}$. Thirst can also be evaluated by the association of laboratory osmolarity analysis with the perception of thirst, covering aspects such as: perceived intensity, desire to drink water, perception of dry mouth, taste in the mouth and gastric satiety ${ }^{(14)}$.

In clinical research, a functional magnetic resonance imaging apparatus and tomography with positron emission has been used to identify the activated brain regions when there is thirst and when it is satiated. It was possible to record temporal changes in blood flow and changes in the chemical composition of brain regions, such as the posterior cingulate ${ }^{(11,16)}$.

In the immediate postoperative period, the visual analog scale has been used for its simple application at a time when patients may have their responses compromised by lowered level of consciousness ${ }^{(1,17)}$.

\section{Response tO SyMPTOM}

It relates to physiological, psychological, socio-cultural and behavioral aspects (Figure 1$)^{(3)}$. Patients with thirst give different answers to this discomfort.

The thirst stimulus is already triggered when the patient is told that they must remain fasting in order to have surgery. It is described that the simple fasting request is a non-regulatory stimulus for the beginning of thirst ${ }^{(18)}$.

Preoperatively, the intensity of thirst increases with the passage of time, and patients use different tactics to relieve it. They may go to sleep in an attempt to ignore the thirst, drink more water than is allowed to take oral medications, think of ways to drink water without being seen, rinse their mouth and gargle, seeking to lessen the stimulus ${ }^{(18)}$. When they dare to verbalize that they are thirsty, they face a team that reinforces the need for maintaining their fast, not offering them any other relief strategy.

Sedated patients also have thirst. When sedation is superficial, they use non-verbal communication to display it. In case of deep sedation, suction movements in oral hygiene were observed, indicating that the patient is thirsty ${ }^{(19)}$. 
For post-operative patients undergoing cardiac surgery in the Intensive Care Unit, being thirsty is distressing; it increases stress and interferes with their recovery. Reports indicate that they are attentive to their environment and there are some who have said that the noise produced by the water from cleaning the floor generates "a desire to jump in the water" $(20)$.

Often the patient seems to be hydrated in the immediate postoperative period because of intravenous fluid replacement. However, there is high incidence of thirst and signs such as dry mouth, dry and chapped lips, and parched tongue. These aspects relate to non-regulatory thirst or "false thirst", when behavioral and psychological factors stimulated by the environment affect the desire to drink water ${ }^{(9,18)}$.

\section{SYMPTOM MANAGEMENT STRATEGIES}

Thirst management aims to prevent or delay a negative result using alleviation strategies. It begins with an assessment of individual experience, followed by identifying an intervention that should be directed to one or more components of the symptom (Figure 1$)^{(3)}$.

Different strategies to relieve thirst in the IPO may be implemented.

Chart 1 - Summary of studies comparing different relief methods and results during IPO - Londrina, PR, Brasil, 2014.

\begin{tabular}{|c|c|c|c|}
\hline Author (Year) & Method and Objective & Sample and Location & Results \\
\hline $\begin{array}{l}\text { Aroni, Nascimento, } \\
\text { Fonseca }(2012)^{(1)}\end{array}$ & $\begin{array}{l}\text { Quasi-experimental; assess thirst re- } \\
\text { lief methods for patients in the im- } \\
\text { mediate postoperative period. }\end{array}$ & $\begin{array}{l}90 \text { patients were divided } \\
\text { into two groups, room } \\
\text { temperature water and ice. } \\
\text { Brazil }\end{array}$ & $\begin{array}{l}\text { The ice group showed a decrease in the in- } \\
\text { tensity of thirst, of } 6.13 \text { to } 1.51 \text {, higher than } \\
\text { that reported by the water group. }\end{array}$ \\
\hline Yoon, Min (2011) $)^{(21)}$ & $\begin{array}{l}\text { Pre-test / post-test; to identify the } \\
\text { effects of gargling with cold water } \\
\text { to relieve thirst and condition of the } \\
\text { oral cavity in patients of the ortho- } \\
\text { pedic clinic. }\end{array}$ & $\begin{array}{l}52 \text { patients were divided } \\
\text { into two groups. South } \\
\text { Korea }\end{array}$ & $\begin{array}{l}\text { The group that received the intervention } \\
\text { exhibited reduced thirst and better condi- } \\
\text { tion of the oral cavity. }\end{array}$ \\
\hline $\begin{array}{l}\text { Cho, Kim, Park } \\
(2010)^{(17)}\end{array}$ & $\begin{array}{l}\text { Quasi-experimental; to examine } \\
\text { the effects of using gauze with a } \\
\text { cold saline solution or ice to relieve } \\
\text { thirst and oral condition in patients } \\
\text { undergoing laparoscopic cholecys- } \\
\text { tectomy. }\end{array}$ & $\begin{array}{l}53 \text { patients received: Fro- } \\
\text { zen gauze with saline solu- } \\
\text { tion }(n=17) \text {, ice }(n=18) \text { or } \\
\text { wet sponge }(n=18) \text {. South } \\
\text { Korea }\end{array}$ & $\begin{array}{l}\text { The group that received frozen gauze with } \\
\text { saline showed a significant decrease in the } \\
\text { intensity of thirst of } 7.88(S D=1.22) \text { to } 2.41 \\
(S D=1) p<0.001\end{array}$ \\
\hline $\begin{array}{l}\text { Hur, Shin, Lee, Lee, } \\
\text { Im, Kim }(2009)^{(22)}\end{array}$ & $\begin{array}{l}\text { Experimental; comparing the hy- } \\
\text { drating effect of gargling ice water, } \\
\text { applying a moist gauze and humidi- } \\
\text { fying in the reduction of thirst and } \\
\text { dryness of the mouth after nasal } \\
\text { surgery. }\end{array}$ & $\begin{array}{l}57 \text { patients gargled with } \\
\text { ice water and applied a wet } \\
\text { gauze; the control group } \\
\text { received humidification of } \\
\text { the oral cavity. South Korea }\end{array}$ & $\begin{array}{l}\text { In three applications, the intensity of the } \\
\text { group's thirst which gargled with ice water } \\
\text { was } 7.63(\mathrm{SD}=1.12) \text { and at the end } 4.79(\mathrm{SD} \\
=0.79-\text { p.000), being more effective than } \\
\text { other strategies. }\end{array}$ \\
\hline
\end{tabular}

According to the results of studies mentioned in Chart 1 , the strategies using low temperature methods have greater efficacy in relieving thirst.

Thirst satiety occurs by two mechanisms: pre-absorption satiety and post-absorption satiety. They respectively occur by oropharyngeal receptor stimulation and decreased blood osmolarity. Activation of oropharyngeal receptors produces a pleasant psychological effect because of the low temperature and thirst relief ${ }^{(9,16,23)}$.

The action mechanism involved is due to the stimulation of oropharyngeal receptors called Transient Receptor Potential Melastatin 8 (TRPM8), which are sensitive to low temperatures and also to menthol substances. This triggers a refreshing sensation and satiety, relieving the discomfort without the ingestion of large volumes ${ }^{(1,17,23)}$. The risk of bronchial aspiration is reduced with gastric volume less than $50 \mathrm{ml}$, which demonstrates the feasibility of the use of ice and water up to this limit ${ }^{(24)}$.

These two strategies, ice and menthol in various formats, open a new level of possibilities for approaching thirst in both pre- and post-operative surgical patients, and still require further study.
Although evidence indicates the effectiveness of low temperature strategies to relieve thirst, these are not yet used in clinical practice in the pre- and post-operative periods, thereby often unnecessarily extending patient's suffering.

To define the best thirst alleviation strategy is not the only management challenge in the immediate postoperative period. Safety aspects in the administration of relief methods are still scarce in the literature. One of the studies developed by GPS resulted in the validation of a Safety Protocol for Thirst Management (SPTM), whose reliability was tested with the objective of providing subsidies to the team to assess safety in the administration of thirst relief methods. The following criteria were grouped (Level of Consciousness, Airway Protection and Absence of Nausea and Vomiting) in a graph algorithm which, alongside with the Operating Procedures and Operating Manual, systematically and intentionally evaluate the safety of administration methods for thirst relief ${ }^{25)}$.

\section{Symptom Outcomes}

Eight factors compose the dimension of symptom outcomes in the Symptom Management Theory: functional state, 
emotional state, mortality, morbidity and comorbidity, quality of life, cost, self-care and symptom status (Figure 1$)^{(3)}$.

Thirst management (evaluation, measurement and adoption of relief strategies) has a positive effect on the functional state of the patient in the perioperative period. Studies show that the distress caused by thirst in the perioperative period causes considerable emotional changes, leading the patient to despair. On the other hand, we observed that after administration of management strategies - especially ice - patients report comfort and almost immediate relief, going from a state of excitement, irritability and anxiety to deep relaxation, even going to sleep after the relief.

As for the evaluation of the impact of strategies on other factors that make up the dimension symptoms outcomes in this theory, further investigation is still necessary including the correlation of the intensity and duration of thirst in the postoperative recovery period and its impact on hospital costs and quality of life of patients. Similarly ,there is still no evidence to correlate physiological signs of stress - such as sweating, pulse and pressure changes - with strategies used to manage thirst that impact the functional state of the patient.

There still are numerous remaining gaps with respect to thirst symptom management and its outcomes, indicating the need to use assessment and management protocols for this symptom for it to become recognized and valued in clinical practice of health services that care for surgical patients.

\section{FINAL THOUGHTS}

The surgical patient belongs to a high risk group for developing thirst. The Symptom Management Theory leads us to consider perioperative thirst in its multifactorial aspects, showing the interrelationship of the domains of the person, the environment, and health / illness state, as well as the dimensions of symptom experience, symptom management strategies and symptom outcomes.

It is expected that these reflections encourage us to purposefully look at the symptom of thirst in surgical patients in clinical practice and to research the many remaining gaps on the subject. This is to meet a pressing and vital human need.

Therefore we stress the importance of developing recognition, measurement, and recording strategies for thirst symptoms relief, guided by scientific evidence. This movement seeks to value thirst as a relevant symptom to the care of the surgical patient, encouraging its introduction into recording instruments of institutions, for patient care in the perioperative period with higher quality and humanization.

\section{RESUMO}

Estudo teórico com o objetivo de analisar, dentro da perspectiva da Teoria de Manejo de Sintomas, o conhecimento existente na literatura sobre o sintoma sede perioperatória, acrescido da experiência do Grupo de Estudo e Pesquisa da Sede. Descreve-se a sede como um sintoma muito intenso e incidente no período perioperatório, por essa razão não pode ser ignorada. A Teoria de Manejo de Sintomas, adequada para a compreensão do sintoma sede, é uma teoria dedutiva, focada nos domínios Pessoa, Ambiente e Estado de Saúde/Doença e nas dimensões Experiência, Estratégias de Manejo e Repercussões do Sintoma. A utilização da teoria nos leva a considerar a sede perioperatória em seus aspectos multifatoriais, analisando a inter-relação de seus domínios e dimensões com o intuito de evidenciar esse sintoma que tem sido insuficientemente valorizado, registrado e tratado na prática clínica.

\section{DESCRITORES}

Sede; Sinais e Sintomas; Enfermagem Perioperatória; Teoria de Enfermagem.

\section{RESUMEN}

Estudio teórico con el fin de analizar, dentro de la perspectiva de la Teoría del Manejo de Síntomas, el conocimiento existente en la literatura acerca del síntoma de la sed perioperatoria, añadido de la experiencia del Grupo de Estudio e Investigación de la Sed. Se describe la sed como un síntoma muy intenso e incidente en el período perioperatorio, por esa razón no se la puede ignorar. La Teoría del Manejo de Síntomas, adecuada para la comprensión del síntoma sed es una teoría deductiva, enfocada en los dominios Persona, Entorno y Estado de Salud/Enfermedad y las dimensiones Experiencia, Estrategias de Manejo y Repercusiones del Síntoma. La utilización de la teoría nos lleva a considerar la sed perioperatoria en sus aspectos multifactoriales, analizando la interrelación de sus dominios y dimensiones con el fin de evidenciar ese síntoma que ha sido insuficientemente valorado, registrado y tratado en la práctica clínica.

\section{DESCRIPTORES}

Sed; Signos y Síntomas; Enfermería Perioperatoria; Teoría de Enfermería.

\section{REFERENCES}

1. Aroni P, Nascimento LA, Fonseca LF. Assessment strategies for the management of thirst in the post-anesthetic recovery room. Acta Paul Enferm [Internet]. 2012 [cited 20 Nov 2013];25(4):530-6. Available from: http://www.scielo.br/pdf/ape/v25n4/en_08.pdf

2. Humphreys J, Lee KA, Carrieri-Kohlman V, Puntillo K, Faucett J, Janson S, et al. Theory of Symptom Management. In: Smith MJ, Liehr PR, editors. Middle range theory for nursing. 2nd ed. New York: Springer; 2008. p.145-58.

3. Dodd M, Janson S, Facione N, Faucett J, Froelicher ES, Humphreys J, et al. Advancing the science of symptom management. J Adv Nurs. $2001 ; 33(5): 668-76$.

4. Millard-Stafford M, Wendland DM, O'Dea NK. Thirst and hydration status in everyday life. Nutr Rev. 2012;70 Suppl 2:S147-51. 
5. Kenney WL, Chiu P. Influence of age on thirst and fluid intake. Med Sci Sports Exerc. 2001;33(9):1524-32.

6. Arai SR, Butzlaff A, Stotts NA, Puntillo KA. Quench the thirst: lessons from clinical thirst trials. Biol Res Nurs [Internet]. 2013 [cited 10 Mar 2014]. Available from: http://brn.sagepub.com/content/16/4/456.long

7. Szinnai G, Schachinger H, Arnaud MJ, Linder L, Keller U. Effect of water deprivation on cognitive-motor performance in healthy men and women. Am J Physiol. 2005;289(1):R275-80.

8. Medeiros VCC, Peniche ACG. The influence of anxiety in coping strategies used duringthe pre-operative period. Rev EsC Enferm USP [Internet]. 2006 [cited 2014 Feb 20];40(1):86-92. Available from: http://www.scielo.br/pdf/reeusp/v40n1/a11v40n1.pdf

9. Arai S, Stotts N, Puntillo K. Thirst in critically ill patients: from physiology to sensation. Am J Crit Care. 2013;22(4):328-35.

10. Bourque CW. Central mechanisms of osmosensation and systemic osmoregulation. Nat Rev Neurosci. 2008;9(7):519-31.

11. Leiper J. Thirst. In: Caballero B, Allen L, Prentice A. Encyclopedia of human nutrition. 2nd ed. Aberdeen (UK): Elsevier; 2005. p. 278-86.

12. Aguilar-Nascimento JE, Dock-Nascimento DB. Reducing preoperative fasting time: a trend based on evidence. World J Gastrointest Surg. 2010;2(3):57-60.

13. Andrew-Romit JJ, Van de Mortel TF. Ritualistic preoperative fasting: is it still occurring and what can we do about it? ACORN J Perioper Nurs Aust. 2011;24(1):14-9.

14. Rolls BJ, Wood RJ, Rolls ET, Lind H, Lind W, Ledingham JG. Thirst following water deprivation in humans. Am J Physiol. 1980; $239(5): R 476-82$.

15. Welch JL. Development of the thirst distress scale. Nephrol Nurs J. 2002;29(4):337-41.

16. Saker P, Farrell MJ, Adib FRM, Egan GF, McKinley MJ, Denton DA. Regional brain responses associated with drinking water during thirst and after its satiation. Proc Natl Acad Sci. 2014;111(14):5379-84.

17. Cho EA, Kim KH, Park JY. Effects of frozen gauze with normal saline and ice on thirst and oral condition of laparoscopic cholecystectomy patients: pilot study. J Korean Acad Nurs. 2010;40(5):714-23.

18. Woodtli AO. Thirst: a critical care nursing challenge. Dimens Crit Care Nurs.1990;9(1):6-15.

19. Landström M, Rehn IM, Frisman GH. Perceptions of registered and enrolled nurses on thirst in mechanically ventilated adult patients in intensive care units- a phenomenographic study. Intensive Crit Care Nurs. 2009;25(3):133-9.

20. Lisboa Gois FC, Aguillar OM, Santos V, Llapa Rodríguez OE. Fatores estressantes para o paciente submetido à cirurgia cardíaca. Invest Educ Enferm. 2012;30(3):312-9.

21. Yoon SY, Min HS. The effects of cold water gargling on thirst, oral cavity condition, and sore throat in orthopedics surgery patients. Korean J Rehabil Nurs. 2011;14(2):136-44.

22. Hur YS, Shin KA, Lee WJ, Lee JO, Im HJ, Kim YM. The comparison of moisturizing effect of cold water gargling, wet gauze application and humidification in reducing thirst and mouth dryness after nasal surgery. J Korean Clin Nurs Res. 2009;15(1):43-53.

23. Eccles R, Du-Plessis L, Dommels Y, Wilkinson JE. Cold pleasure: why we like ice drinks, ice-lollies and ice cream. Appetite. 2013;71:35760.

24. Perlas A, Davis L, Khan M, Mitsakakis N, Chan VW. Gastric sonography in the fasted surgical patient: a prospective descriptive study. Anesth Analg. 2011;113(1)93-7.

25. Nascimento LA, Fonseca LF. Development of a safety protocol for management of thirst in the immediate postoperative period. Rev Esc Enferm USP. 2014;48(5):834-43. 